Eos, Vol. 66, No. 7, February 12, 1985

Kimberlites I:

Kimberlites and Related

Rocks

Kimberlites II:

The Mantle and CrustMantle Relationships

\section{PAGE 63}

Proceedings of the Third International Kimberlite Conference, Jacques Kornprobst (ed.), Elsevier, New York, vol. I, xiv +466 pp., 1984 ,

$\$ 53.75$; vol. II, xiv + 393 pp., 1984, $\$ 50.00$.

\section{Reviewed by Arden L. Albee}

These volumes open with a tribute to academician Vladimir Stepanovich Sobolev, who died several days before the opening of the Third International Kimberlite Conference at Clermont Ferrand, France. V. S. Sobolev made major contributions to the field of kimberlite and upper mantle petrology throughout his lifetime and did much to spark the renaissance in this field that led to these conferences.

The 28 papers in the first volume deal with the petrology, geochemistry, and structures of kimberlites and related rocks or with the processes by which the kimberlites were derived. The 29 papers in the second volume deal with the mantle and crust-mantle relationships. The papers represent a good sam pling of the excellent work that is currently being carried out in this field. A few of the papers are reviews, but most are new work with abundant analytical data on the rocks and their contained minerals. The papers describe a good sampling of the global occurrences, with the exception of those in the Soviet Union.

Volume I deals with kimberlites and starts with three papers on the detection of poorly exposed kimberlite pipes in North America, East Africa, Siberia, and India. Nine detailed papers describe the geology, petrology, mineralogy, and geochemistry of occurrences of kimberlites and related rocks, including a paper on oceanic carbonatites. Five general synthesis papers describe kimberlite occurrences in China and Western Australia and ultrapotassic rocks in Western Australia and Spain. The concluding 11 papers comprise analytical, experimental, and theoretical attempts to understand the physical and chemical processes involved in the formation of these intriguing rocks.

The initial 16 papers (204 pages) of volume II are detailed petrology and geochemistry studies on mantle rocks from a variety of sources, both geologically and geographically. Included are several studies of quite rare $x e$ noliths, such as a kyanite-coesite-sanidine garnet pyroxenite, and several studies of inclusions in diamonds. The succeeding three papers are similarly detailed studies of xenoliths from the lower crust. The concluding $10 \mathrm{pa}$ pers mostly involve theoretical constraints or general considerations on the dynamics of the mantle. However, they include two experimental studies, one on the phase relations between coexisting garnet and two pyroxenes at high pressure and one on the enstatite-diopside solvus to $60 \mathrm{kbars}$

The book was printed from camera-ready copy, but the editor and the publisher have done an exceptional job of making the copy appear uniform. Most remarkably, even the photographs, maps, and tables are crisply leg ible. The references have been collected to the end of each volume, thereby providing a very convenient, up-to-date access to the literature. I expect that workers in this field will have already added these volumes to their library-therefore I can only recommend the volumes highly to those others with peripheral interest in the mantle.

Arden L. Albee is with the Division of Geological and Planetary Sciences, California Institute of Technology, Pasadena.

\section{A \\ Executive \\ Committee and Council Actions}

\section{PAGE 66}

The AGU Council and Executive Committee met in San Francisco during the AGU Fall Meeting. The Council next meets on Tuesday, May 28, 1985, in Baltimore. The Executive Committee will meet in March and then again just prior to the Council meeting in Baltimore.

\section{Highlights of the Recent Meetings}

- Approved a Chapman Conference on the Modeling of Rainfall Fields, to be held in Caracas, Venezuela, March 24-26, 1986. Also approved the cosponsorship of several meetings of other societies. Cosponsored meetings are allowed the use of AGU mailing lists and are announced in Eos: no financial obligation is incurred by the Union.

- Approved a new honorarium schedule for journal editors for 1985.

- Approved a scope statement for the new paleoceanography journal. Agreed on schedule for a similar statement for the new journal dealing with global chemical cycles. Publication of the two is slated for 1986 .

- Amended the AGU Bylaws to eliminate the Membership Committee as a standing committee. This proposed action had been reported in Eos (September 4, 1984, p. 687) after initial passage by the Council in May 1984. Two considerations of bylaw changes are required before they can become effective.

- Approved a plan submitted by the Mineral Physics Committee to establish a subcommittee that will attempt to arrange for the production of mineral samples of specified composition, size, and purity for eventual general distribution to scientists. The subcommittee is to prepare and submit proposals for the funding of the production of these mineral samples, to issue requests for proposals to industry, and to insure that the product delivered is satisfactory. AGU will act as the contracting agency and distributor of the samples.

- Agreed to :onduct two awards ceremonies in 1985 . In the past the awards have all been presented during the AGU Spring Meeting. There has been concern that the number of awards has cut down the opportunity for appropriate citations and responses. Spreading the awards over two ceremonies will allow more members to attend and permit time to make the program more meaningful.

- Extended the Science Policy Seminar Program of the Public Affairs Committee an extra year. This program is advertised in Eos from time to time.

The Council also approved AGU's first 3year plan. This plan was put together by a committee including all of the Executive Committee members and the principal com- mittee chairmen and was reviewed by the section presidents and presidents-elect. The plan details goals for the Union and the sections over the next 3 years. It will serve as a guide and stimulus for AGU activities. Presidentelect Eagleson, who chaired the Planning Committee, will be presenting the plan to the membership in an editorial in Eos shortly. The Executive Committee asked the Executive Director to begin the process of formal application for membership in the American Institute of Physics.

\section{AGU Elects \\ 17 Fellows}

\section{PAGE 66}

Seventeen distinguished scientists have been elected Fellows of AGU. The total number of Fellows elected each year may not exceed $0.1 \%$ of the total membership at the time of election.

The newly elected Fellows are

- Claude J. Allegre, Institute of Physics, University of Paris

- Peter M. Banks, Department of Electrical Engineering, Stanford University

- Robert G. Coleman, Department of Geology, Stanford University

- Francis A. Dahlen, Jr., Department of Geological and Geophysical Sciences, Princeton University

- Michael D. Fuller, Department of Geological Sciences, University of California, Santä Barbara 